\title{
A Review of Communicative Translation Approach Based on Multiple Texts
}

\author{
Xiangqing Bai \\ East China University of Science and Technology, Shanghai, China \\ Email: 1666165631@qq.com
}

How to cite this paper: Bai, X.Q. (2020) A Review of Communicative Translation Approach Based on Multiple Texts. Open Access Library Journal, 7: e6938.

https://doi.org/10.4236/oalib.1106938

Received: October 27, 2020

Accepted: November 24, 2020

Published: November 27, 2020

Copyright () 2020 by author(s) and Open Access Library Inc.

This work is licensed under the Creative Commons Attribution International License (CC BY 4.0).

http://creativecommons.org/licenses/by/4.0/

\section{(c) (i) Open Access}

\begin{abstract}
Peter Newmark's translation theories have been widely used in translation application and have been attached a great deal of importance in the translation studies. This paper made an analytical review of Newmark's communicative translation approach based on multiple texts in two articles at first. And the review finds that there are some inappropriate classifications between communicative translation approach and semantic translation approach in the two articles, as well as unsolvable and impracticable problems remained in translation practice despite the guidance of Newmark's communicative translation approach. Based on process-oriented approach and result-oriented approach in pragmatic principle of Chinese and English translation by Wang Jianguo, this paper finds that these unsolvable and impracticable problems in practical translation may well have a reasonable explanation to go and have practical cognition guidance for translators. As a version of English to Chinese translated book implies, this paper further shows how process-oriented approach and result-oriented approach affect, and the orientation differences in pragmatic principle between two versions. Based on what has been analyzed, this paper concludes some translation methods in translation practice.
\end{abstract}

\section{Subject Areas}

Linguistics

\section{Keywords}

Communicative Translation, Process-Oriented Approach, Result-Oriented Approach

\section{Introduction}

Peter Newmark's Approaches to Translation has been widely used on translator 
training course and combined a wealth of practical examples of linguistic theories of meaning with practical applications for translation. Newmark suggests that communicative translation attempts to produce on its readers an effect as close as possible to that obtained on the readers of the original. Semantic translation attempts to render, as closely as the semantic and syntactic structures of the second language allow, the exact contextual meaning of the original [1].

Indeed, Newmark's communicative translation approach has played such a significant part in translation theory studies and development that so many translators, teachers and translation-related stuff have applied communicative translation approach to translation practice. And in cross-cultural situations, communicative translation approach has also set a certain place to reach some communicative activities or goals in terms of bilingual and bicultural communication rules or regularities. Nevertheless, there exists some misunderstanding in Newmark's communicative translation when it is being applied. And there are some unsolvable and impracticable problems in practical translation even with the guidance of communicative translation approach. And we can get this message from many articles which have appointed communicative translation approach as their core principle theory. And in the following part, this paper will take two articles as an example, to have an analytical review about communicative translation theory they have employed.

\section{Review on Communicative Translation Approach}

Peter Newmark's most well-known contribution to translation lies in his communicative translation theory and semantic translation theory. Especially, most translators have a tendency to couple communicative translation theory with translation practice, in particular its conducting direction toward literature translation practice. And as a general rule says, every theory has its merits and defects in relation to conducting the performance. And communicative translation theory does, as well. Therefore, it is of great importance to have an analytical review toward communicative translation theory in related articles, and to probe into these defects that communicative translation theory is coupled with when doing translation activities. Then we can make better use of communicative translation theory and avoid its defects, to yield its value to the best to guide or improve our translation practice.

\subsection{Cases of Chinese to English Translation: Examples from the Story of the Stone}

In this part, this paper will take the article Translation of Granny Liu's Characteristic Language: A Comparative Study of the Two English Version of Hong Lou Meng [2] by Xu Mengyang as an example for case study. In this article, Xu mentioned Granny Liu's Characteristic language as texts to analyze the translation methods from the perspective of semantic translation approach and communicative translation approach by comparing Yang Hsien-yi and Gladys Yang's 
translated version [3] and David Hawkes and John Minford's English version [4]. In addition, this article has demonstrated the elements that have affected the translation strategies, and further has discussed the advantages and disadvantages of the translation strategies. And this paper will select several cases of the language examples to carry out an analytical opinion about Xu's ideas.

Example 1: 姑爷, 你别嗔着我多嘴。

Yang: You mustn't mind me butting in, son-in-low [3].

Hawkes: Now looks here, son-in-low: probably you will think me an interfering old woman [4].

Example 2: 好呀? 周嫂子。

Yang: Sister Zhou! How are you? [3]

Hawkes: How are you, my dear [4].

Example 3: 这位凤姑娘, 今年不过十八九罢了。

Yang: This young mistress Feng can't be more than twenty [3].

Hawkes: “This Mrs. Lian,” said Grannie Liu: “she can't be more than eighteen or nineteen years old" [4].

$\mathrm{Xu}$ has commented:" From the discussion, it is evident that the Yang's version seems more polite. Meanwhile Yang expressed the peasant status of Liu and the status gap between Liu and the people of Jia, and also retained the characteristics of ancient class. In a word, in the part of addressing terms, Yang's translated version belongs to semantic translation. And because of the different cultural background, Hawkes' version looks more Western, which belongs to communicative translation" [2].

For example 1, Yang and Hawkes respectively has applies "butt in" and "think me as an interfering old woman” to the Chinese characters “多嘴”. Yang's “butt in" is more explicit compared with Hawkes' "think me as an interfering woman". "But in" is more colloquial in the terms of communication. Yang has a likely tendency to use verb phrase, while Hawkes uses more implicit phrase because he chooses a noun phrase. Hawkes, a translator with English as his mother tongue, remains his language use habit that English is a static language. Then Hawkes turns Chinese verbs into English noun phrase. And "think me as an interfering old woman" is one step further than "butt in", which shows the result of Liu's "butt in". For example 2, similarly, we can see that Hawkes' translated version "my dear" is one step further than Yang's translated version "Sister Zhou". From the perspective of fidelity with the source text, Yang is trustier. From the perspective of pragmatic principle, Hawkes is further more in keeping equivalence with the source text. Therefore, we cannot judge which is better or not on a single hand. For example 3, the difference between the two translated versions lies in the translation of “凤姑娘”. And we can see clearly that “Mrs. Lian" is one step further than "young mistress Feng". Because according to traditional Chinese addressing terms, a married woman should be addressed in the line with her husband.

To sum up, Yang's translated version also attempts to produce on its reader 
an effect as close as possible to that obtained on the readers of the original. Hawkes's translated version also keeps as closely as the semantic and syntactic structures of the second language, the exact contextual meaning of the original. To some extent, it is of less meaning to distinguish communicative translation from communicative translation. And in the terms of the concept of the communicative translation and semantic translation, it is doubtful that whether translators are reminding of the concept or rendering according to the description of what is the communicative translation and what is the semantic translation. On the other hand, English language and Chinese language has its own features and characteristic, which is the basic element of the two languages. Therefore, if translators from the pragmatic language use features, or we say principles, it is wiser and is of more helpful guidance to do translation practice. And to turn around, the translated texts will relatively close to its source texts from pragmatic perspective.

Example 4: 咱们村庄人家儿, 那个不是老老实实, 守着多大碗儿吃多大的 饭呢。

Yang: We villager are simple honest folk who eat according to the size of our own bowl [3].

Hawkes: we country folk have to be grateful for what is in the pot and cut down our appetites to the same measure [4].

Example 5: 瘦死的骆驼比马大。

Yang: A starved camel is bigger than a horse [3].

Hawkes: A starved camel is bigger than a fat horse [4].

Example 6: 老刘, 老刘, 食量大如牛。吃个老母猪, 不抬头!

Yang: Old woman Liu, I vow. Eats more than any cow, and down she settles now to gobble an enormous sow [3].

Hawkes: My name it is Liu, I am a trencherman true; I can eat a whole sow with her little pigs too [4].

$\mathrm{Xu}$ has commented:" As for the accuracy of language, Yang's translated version is higher than Hawkes' translated version. The Yang focused on conveying the original meaning exactly, which belongs to the semantic translation. However, Hawkes focused on the target text and target text readers. It is more like in paraphrase, which belongs to communicative translation" [2].

For example 4, Yang's translated version tends to appear word for word translation, which is closely related with the source text. Of course, in this extent, it is more available for readers to understand the original text, and reach the feelings about Granny Liu's status and situation when she was delivering her speech. In this sense, the translated version of Yang is communicative feasibly. But, it is not reasonable to deem that Yang's translated version is not semantic or syntactic equivalent with the original text. Of course, only when this sentence is equipped with semantic equivalence of the source text, can the readers comprehend better and this translation practice work well. For Hawkes's translated version, first we can see clearly that Hawkes is more likely to employ sense for sense 
translation. After all, he adds his cognitive feeling of Granny Liu's emotional attitude when Liu is speaking this sentence to his translated sentence. However, for readers who are born with English language speaking, Hawkes' translated version is so considerate for the reason that he has employed English speaking custom. And he has translated this sentence from the other round, to let readers better understand. In this case, Hawkes' translated version is communicative available. Therefore, there is no clear-cut line in this aspect between communicative translation and semantic translation in the cases of Yang' and Hawkes' translated sentence. Then, how can we analyze their translated work? And in what aspect should we stand to reach a relatively universal but not respectively distinguished principle? In the sense of language using or we can say, pragmatic principle, it is a universally applied rule, because language feature is unchangeable. And it is of great meaning when we are doing translation practice. For example, when we see Yang's and Hawkes' translated version of example 4. We can make a conclusion that Hawkes's translated version is one step further than Yang's translated version. And Hawkes' translated sentence shows the emotional result of the Yang's translated sentence. Yang's translated sentence shows more about how the village is honest, the specific issues concerned with their honest. In other words, Yang has pictured the tangible description or process of how the villagers are honest.

For example 5, clearly, the mere difference between Yang's and Hawkes' translated version lies in "a horse" or "a fat horse". From the perspective of original sentence, Yang is more concentrated on the word for word translation, which is more literal and facial. It is more communicative, but it may not semantic available for readers. And readers might as well have doubt about the meaning behind it. While Hawkes' translated version focuses more on the sense for sense translation, which conveys more the inner meaning and reflective understanding of this sentence. Therefore, it is more semantic availably. Because Hawkes has added "fat" to modify "horse", to connote that the camel is thin and starved. Here, we can make a conclusion that Hawkes's translated version is one step further than Yang's translated version. And Hawkes' translated sentence shows the comparative result of the Yang's translated version.

For example 6, it is obvious that Yang follows the original text in his translation, and his translated sentence is more closed with the original characters and features of the language Granny Liu has spoked. On the one hand, it is communicative enough to convey the original meanings, the language features and the vivid image of the character to the readers. On the other hand, Yang uses "vow", "cow", "now", "sow" in this translated sentence. Thus, it keeps syntactic structure with the original text. And the translated sentence shows the vulgarity of the words, which well serves Granny Liu's character. When it comes to Hawkes' translated sentence, it is more semantic. And it is less vulgar when compared with Yang's translated version. And Hawkes' translated version is more explicit in this sense. Therefore, we can say, Hawkes' translated sentence is more re- 
sult-oriented to be explicit enough. And Yang's translated sentence is more process-oriented to be implicit in this sense.

\subsection{Cases of English to Chinese Translation: Examples from the Comfort of Strangers}

In this part, this paper will take some examples from The Comfort of Strangers, which is cited from the article The application of Newmark's translation theory in prose translation: take The Comfort of Strangers as an example [5] by Li Yanran. In this article, Li has mentioned the application of Newmark's translation theory to the prose The Comfort of Strangers. In the fourth part of the article, $\mathrm{Li}$ has discussed two parts, referring to the semantic translation application in The Comfort of Strangers, and the communicative translation application in The Comfort of Strangers. The former consists of three sections, including remaining words, remaining syntaxes of the original text, and remaining rhetorical methods of the original text. The latter consists of three sections, including getting rid of words limits of the original text, employing native expressions of the source language, and breaking logical limits of the original text. Here, we merely take the latter, which belongs to the communicative translation, into consideration. At last, Li has made a conclusion that literature translation belongs to a tough job [5]. And by applying Newmark's translation theory, it is of great guidance and huge meaning on literature translation practice. And therefore, we ought to take notice on combining translation theory and translation practice. Only in this way, could we reach the mixture of instinct and rationality when we do translation practice, and could we reach closer to the true nature of translation work than the conscious translation practice. Following is the analytical review.

Example 1: The transition between life in red-state America and life in the Arab capital was at times overwhelming because of the traditional segregation of men and women in many public and private settings [5].

Translated version: 从美国的红色之州(支持共和党的州)到阿拉伯国家的首 都, 我时常感到难以接受生活的转变, 因为在开罗的许多公共场合和私人场 合, 男女之间还保持着传统的隔离状态 [5]。

This example shows the word using transition between the original text and the translated text. The English noun phrase "red-state America" in the original text refers to state Colorado. Here the translated version uses “红色之州(支持共 和党的州)”. And this Chinese translation not only makes an explanation of the place's political connotation, which refers to the part supporting the Republic Party, but also denotes the place's geographical features, which owns red sandstone and features its reddish land views. Therefore, we can say that this Chinese translation not only displays the state's political meaning, but also its cultural value. Therefore, we can see, Chinese translation pays more attention on the words process behind The English word "overwhelming" in the original text is an adjective, which modifies the noun transition. While in the Chinese transla- 
tion, it turns the adjective into a verb phrase “感到难以接受......的转变”. On the one hand, it makes the Chinese translation more fluent and smoother to close the pragmatic principle of Chinese language. On the other hand, it transfers a kind of state into a process of motion, which is more vivid to convey the emotional change of the author who has experienced the movement of livelihood from America to the capital of Arab. Therefore, we can see, Chinese translation pays more attention on the motion process of the English word "overwhelming".

Example 2: “Take the candies and say, 'Thank you, Aunt,' or don't take them and say, 'No, thank you, Aunt,' and then come sit here next to me and Auntie," their mother repeated [5].

Translated version: “拿糖就要说“谢谢你, 阿姨’, 要不就别拿, 跟阿姨说“不 用了, 谢谢你阿姨', 然后过来坐在我和姨姨旁边。”[5]

This example shows the native expression of the translated text toward the original text. Owing to in the original text, "Auntie" is non-formal usage of "Aunt". In the original text, this sentence is from a young mother who addresses a stranger, in front of her child. And here, this Chinese translation compromises to the speaking characteristic to a child, and can convey reader' renounce, and arose the common feeling. Otherwise, this effect cannot be achieved. Therefore, we can say, the translation of the addressing details can not only reflect the semantic equivalence of the original text, but also the communicative purpose for the readers' sake. And this effect may be more helpful after doing this translation practice, and it is of more value to have a judge about the translation work. But, when we are doing the translation practice, maybe it is better to let the pragmatic principle of English and Chinese lead our thought and affect our instinct.

Example 3: In my case, all it took was a single ride in a mixed car, where unescorted women are frequently targets of harassment and religious censure, to make me grateful for the decidedly un-Western amenity of the women's compartment [5].

Translated version: 对我而言, 只要坐一次混合车厢, 就会使我对女性车厢 这种明显很不西化的便利设施充满感激, 因为在混合车厢里无人陪同的女性 经常被骚扰, 还要面对谴责[5]。

This example shows that the translated version gets rid of the logic limit of the original text. In the original text, "unescorted women are frequently targeting of harassment and religious censure" is a definite phrase to modify "car". While in the translated text, the translator does not use the definite phrase as an attributive phrase to modify the word "car". While, the translator adjusts the logic order of the sentence, and turn the attributive phrase into a sentence to explain the reason for being grateful. In addition, in the original text, women are seemed as "targets" of harassment and religious censure. While in the translated text, the meaning of the word "target" has been connoted, and it is not translated explicitly. Besides, the translator turns it into a dynamic sentence pattern, which is “被......". Therefore, in terms of syntactic order, and word meaning, the Chi- 
nese translated version pays more attention on the process of word motion, which is in the state of being dynamic. On the other hand, English text is more static and pays more attention on the result of the motion.

\section{Pragmatic Effect on Chinese Translated Book}

After discussing several examples in two articles that concerns Newmark's communicative translation theory, this paper has analyzed and confirmed pragmatic principle between English language use and Chinese language use, and particularly, this paper concluded that the process-oriented approach in English language should be noticed when translators are doing English to Chinese translation practice. Here, this section discusses pragmatic effect on Chinese translated book by Lin Hua of From Dawn to Decadence [6] with the two approaches, referring to process-oriented approach and result-oriented approach in pragmatic principle of Chinese and English translation by Wang Jianguo [7].

From Dawn to Decadence [8] was created by Jacques Barzun, an American scholar. This book is a great work that Jacques Barzun has produced after he has studied the whole western culture in 1500. It also represents a huge work among cultural treatises in the 20th century. And critics have praised this work as a milestone in the history of cultural work creation. The reason why here this paper has applied this book is that this book has discussed all aspects of Western socio-cultural life for about 500 years from 1500 to the present, including: political institutions (such as monarchy), religion, social trends of thought, philosophy, literature, music, fine arts, technological inventions, folklore, and society life and so on, which are all-encompassing and cover a wide range. From the roots of the Renaissance to rap music, the writer has narrated and incorporated the thoughts he has made during his long lives, making the book rich and unique. The author believes that our time is a period of cultural decline. He has pointed out that there are currently many annoying factors, such as deadly politics, obedience to school education, the spread of individualism, and the prevalence of highly abstract art, but the decline of culture does not mean that disappointment exists more than hope, but is likely to be the source of Western revival. Here are some examples in From Dawn to Decadence by applying them we can have a further understanding of pragmatic principles in translation practice.

Example 1: THE MODERN ERA BEGINS, characteristically, with a revolution. It is commonly called the Protestant Reformation, but the train of events starting early in the $16 \mathrm{C}$ and ending-if indeed it has ended-more than a century later has all the features of a revolution. I take these to be: the violent transfer of power and property in the name of an idea [8].

Translated version: 现代社会以一场革命开端，与这一时代的特征恰好吻 合。这场革命统称新教改革, 然而, 从16 世纪改革开始, 到一个世纪以后改 革结束(是否真的结束了还是个疑问), 前前后后发生的一连串事件都具备了 革命的特征：为实现某个信念，通过暴力造成权力和财产的易手 [6]。

In this example, it talks about the Protestant Reformation and the typical fea- 
ture of revolution. First, we can see the translation of the time. In the original text, there is "early in the $16 C$ ", which is translated into " 16 世纪”. It is obvious to see that in the translated text, the message "early" is missed, and it is not translated. While, in the prior part of this book, the author has mentioned that he had applied "early", "middle", and "late" to indicate time more exactly. Therefore, translator should pay attention to this detail and try to be exactly as possible when doing translation practice in association with time and try to be close to the original text in expressing something which pursues exactness. And the same is as the "more than a century later" in the next sentence. The more exact modifier of "a century", which is "more than", is missed and not translated. Second, we have a look at the last sentence: the violent transfer of power and property in the name of an idea. In the first place, "in the name of an idea" in the original text has been rendered into “为实现某个信念”. In the original text, there is a noun phrase, and idea is modified by “in the name of". It is a static state to indicate the reason or purpose of revolution. Then in the translated version, the translator turns the motionless state into a purpose with motion, which is rightly correspondent with the Chinese language pragmatic principle.

Therefore, we can say this translated sentence shows the process of the expression the original sentence tries to convey. In the second place, the other part of this sentence: "the violent transfer of power and property", is translated inappropriately. We can see that the transfer is violent which is caused by power and property. And here, "transfer" means that the owners or possessors of the property have gone through alternated. While, in the Chinese translated version, violence has been a path, and power and property have been a result caused by violence to modify the word "transfer". After analyzing, we can see that the translator has misunderstood the original text in this sentence. Although it has applied the process-oriented approach in the latter part of this sentence, it cannot avoid delivering the inaccurate messages.

Example 2: Given a new device or practice that changes our homely habits, we exclaim: “revolutionary!” [8]

Translated version: 一有改变我们习性的新发明或新做法出现, 我们立刻惊 呼“革命了! ”[6]

This example depicts that revolution means that something new happens in people's life which has influenced or even changed their ways of living. In the original text, "revolutionary" is an adjective to describe a situation which is completely new and different, especially in a way that leads to great improvements. We can say that it is a static situation obviously. On the other hand, in the translated version, it uses a three-character word which reflects dynamic motion rather than static state. Again, the Chinese translated sentence has proved its process-oriented pragmatic principle on the form of words of speech. By using the pattern of a verb and a functional word, the translated version transfers a descriptive state into a process of moving.

Nevertheless, there are also some translated sentences which do not obey 
process-oriented principle. And we can have a discussion on whether this kind of pragmatic principle has influence on the pragmatic effect. Here are some examples.

Example 3: To call the first of the four revolutions religious is also inadequate. It did indeed cause millions to change the forms of their worship and the conception of their destiny [8].

Translated version: 把四次革命中的第一次革命称为宗教革命也是不全面 的。确实, 这次革命使几百万人改变了信仰的形式和对命运的认识[6]。

This example shows the first reason that the Reformation is so important that it has brought a huge influence on people and their cognition. In English, "the forms of the worship" and "the conception of the destiny" tends to use abstract noun and the form of preposition to describe the religious influence on people's life. In Chinese translated version, the translator uses abstract noun, and auxiliary verb which links two abstract nouns, and the latter noun belongs to an external part of the abstract noun. Absolutely, it does not cater to the principle of the language use. Maybe readers can have a general understanding about the influence but cannot feel the development of the influence.

Example 4: No longer always in Latin for clerics only, but in one of the common tongues, the $16 \mathrm{C}$ literature of biblical argument and foul invective began what we now call the popularization of ideas through the first of the mass media [8].

Translated version: 16 世纪有关《圣经》理论的文章以及彼此攻讦的文章不 再完全用拉丁文来写作, 专供僧侣阅读了, 已经开始使用比较流行的方言, 通过新生的大众媒体手段向民众宣传推广各种思想[6]。

This example talks about the influence on clerics and literature in $16 \mathrm{C}$ because of the Reformation. In English, "the popularization of ideas" is a typical nominalization pattern in language use and abstract noun to describe the way that thoughts have been spread. In Chinese translated version. The translator uses the verbal form to describe the way literature conveys thoughts and ideas to the public. It is a moving process.

\section{Conclusion}

Firstly, this paper has made an analytical review of Newmark's communicative translation approach based on multiple texts in two articles: Translation of Granny Liu's Characteristic Language: A Comparative Study of the Two English Version of Hong Lou Meng [2] by Xu Mengyang and The application of Newmark's translation theory in prose translation: take The Comfort of Strangers as an example [5] by Li Yanran. And the review finds that there are some inappropriate classifications between communicative translation approach and semantic translation approach in the two articles, as well as unsolvable and impracticable problems remained in translation practice despite the guidance of Newmark's communicative translation approach. Based on process-oriented approach and result-oriented approach in pragmatic principle of Chinese and English transla- 
tion by Wang Jianguo [7], this paper finds that these unsolvable and impracticable problems in practical translation may well have a reasonable explanation to go and have practical cognition guidance for translators. As a version of English to Chinese translated book of From Dawn to Decadence by Lin Hua implies, this paper further shows process-oriented approach works in a part of speech when doing translation practice after a general analysis of the orientation differences in pragmatic principle between two versions. Therefore, mastering translation practice is a fundamental tool for doing translation practice, while there are still some practical problems remained when rendering. Luckily, the process-oriented pragmatic principle in Chinese has been confirmed, which is of great help and guidance for sound translation practices.

\section{Conflicts of Interest}

The author declares no conflicts of interest regarding the publication of this paper.

\section{References}

[1] Newmark, P. (1981) Approaches to Translation. Prentice Hall International (UK) Ltd., New York.

[2] 许孟杨. 评析《红楼梦》两个英译本中刘姥姥的个性话语翻译[D]: [硕士学位论 文]. 武汉: 华中科技大学, 2017.

[3] Cao, X.Q. (1978) A Dream of Red Mansion (Translated by Yang Hsien-Yi and Gladys Yang). Foreign Language Press, Beijing.

[4] Cao, X.Q. (1973) The Story of the Stone (Translated by David Hawkes and John Minford). The Challcer Press Ltd., Richard Clay.

[5] 李懳然. 纽马克翻译理论在散文翻译实践中的应用一一以翻译《来自陌生人的慰 藉》为例[J]. 智库时代, 2020(1): 218-219.

[6] 雅克.巴尔赞, 著. 林华, 译. 从黎明到衰落[M]. 北京: 中信出版社, 2002.

[7] 王建国, 何自然. 重过程, 还是重结果? -一译者的母语对英译文本的影响 [J]. 上海翻译, 2014(2): 7-12.

[8] Barzun, J. (2000) From Dawn to Decadence [M]. HarperCollins Publishers Inc., New York. 